\title{
Nerve ultrasound and 3D-MR neurography suggestive of intraneural perineurioma
}
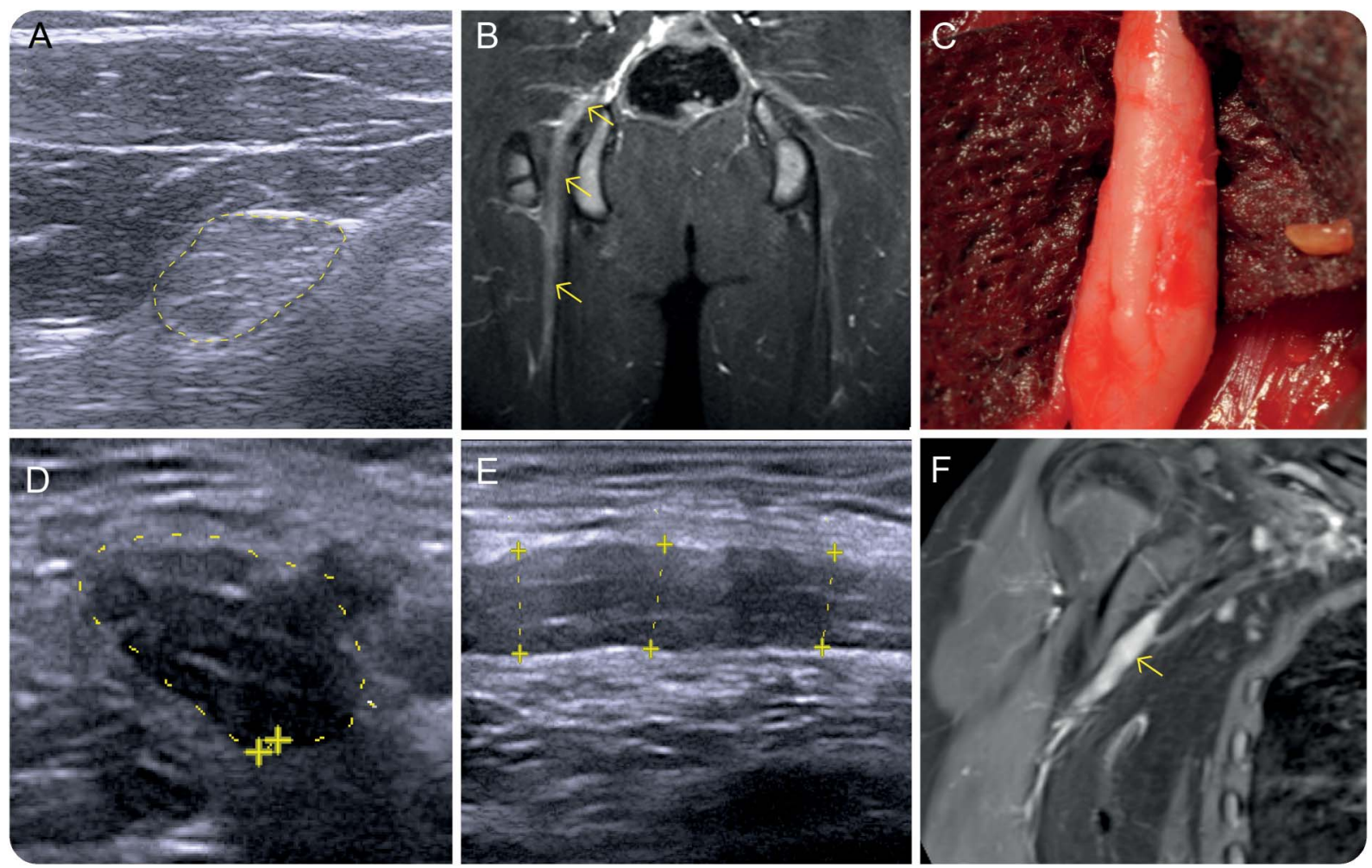

Right sciatic nerve: enlargement (cross-sectional area $35 \mathrm{~mm}^{2}$ ) revealed by ultrasound (US) and surgical inspection (A-C); increased signal intensity on 3Dmagnetic resonance (MR) neurography, reformatted coronal maximum intensity projection view (B). Cross-sectional area left sciatic nerve: $14 \mathrm{~mm}^{2}$. Left radial nerve: US showed cross-sectional area enlargement $40 \mathrm{~mm}^{2}$ (normal values $\leq 8 \mathrm{~mm}$ ), $6 \mathrm{~cm}$ long and 4.4-4.8 mm wide (D-E); MR neurography, coronal oblique postcontrast T1 fatsat (F): enhancement and fusiform enlargement.

Supplemental data at Neurology.org
An 8-year-old girl presented with progressive painless right peroneal and tibial nerve palsy. A 20-year-old woman had insidious weakness of the left wrist and fingers extension. Both underwent neurophysiology (tables e-1 through e-4 on the Neurology ${ }^{\circledR}$ Web site at Neurology.org) and nerve ultrasound that showed enlargement of sciatic (figure, A) and radial nerve (figure, D-E). A 3D-magnetic resonance (MR) neurography examination detected a 20-cm-long uniform enlargement of sciatic nerve (figure, B) and a 6-cm-long fusiform enlargement of radial nerve (figure, F) with mild hyperintensity and marked contrast enhancement, suggesting intraneural perineurioma. ${ }^{1,2}$

Both had surgical exploration but not biopsy: the macroscopic and imaging appearance (figure, C), texture, and clinical history (young age, progressive motor symptoms) strongly suggested the diagnosis intraoperatively. ${ }^{3}$

Intraneural perineurioma is a rare benign nerve tumor presenting in youth. MR neurography aids the diagnosis, possibly avoiding nerve biopsy when there are typical MR features.

Alessandro Salvalaggio, MD, Mario Cacciavillani, MD, Daniele Coraci, MD, Carmen Erra, MD, Roberto Gasparotti, MD, Stefano Ferraresi, MD, Luca Padua, MD, Chiara Briani, MD

From the University of Padova (A.S., C.B.); CEMES-EMG Laboratory (M.C.), Data Medica Group, Padova; "Sapienza” University (D.C.), Rome; Don Gnocchi Foundation (D.C., L.P.), Milan; Catholic University of the Sacred Heart (C.E., L.P.), Rome; University of Brescia (R.G.); and Rovigo Hospital (S.F.), Italy. 
Author contributions: Alessandro Salvalaggio and Chiara Briani are the neurologists in charge of patient 1 and wrote the draft of the manuscript. Mario Cacciavillani is the neurologist who performed the neurophysiologic/EMG as well as nerve ultrasound evaluation of patient 1. Daniele Coraci and Carmen Erra are the physicians in charge of patient 2 and performed the neurophysiologic/EMG study. Luca Padua is the neurologist who performed the nerve ultrasound evaluation of patient 2. Roberto Gasparotti performed MR neurography on both patients. Stefano Ferraresi performed surgical exploration in both patients. All the authors helped in the analysis and interpretation of data. All the authors read and approved the final version of the manuscript.

Study funding: No targeted funding reported.

Disclosure: The authors report no disclosures relevant to the manuscript. Go to Neurology.org for full disclosures.

Correspondence to Dr. Briani: chiara.briani@unipd.it

1. Mauermann M, Amrami K, Kuntz N, et al. Longitudinal study of intraneural perineurioma: a benign, focal hypertrophic neuropathy of youth. Brain 2009;132:2265-2276.

2. Ahlawat S, Chhabra A, Blakely J. Magnetic resonance neurography of peripheral nerve tumors and tumorlike conditions. Neuroimaging Clin N Am 2014;24:171-192.

3. Ferraresi S, Garozzo D, Bianchini E, Gasparotti R. Perineurioma of the sciatic nerve: a possible cause of idiopathic foot drop in children: report of 4 cases. J Neurosurg Pediatr 2010;6:506-510.

\section{Subspecialty Alerts by E-mail!}

Customize your online journal experience by signing up for e-mail alerts related to your subspecialty or area of interest. Access this free service by visiting Neurology.org/site/subscriptions/etoc.xhtml or click on the "E-mail Alerts" link on the home page. An extensive list of subspecialties, methods, and study design choices will be available for you to choose from—allowing you priority alerts to cutting-edge research in your field!

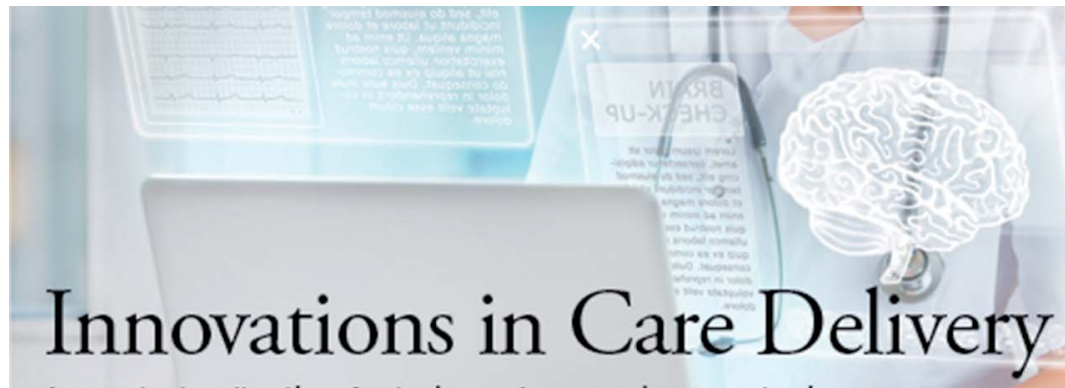

A curated collection featuring advances in neurologic care

\section{NEW! \\ Innovations in Care Delivery - A curated collection featuring advances in neurologic care}

This Neurology ${ }^{\circledR}$ special interest Web site provides a forum to explore new care models from multiple disciplines, access to sources on health care innovation, and expert opinions on current research from Neurology journals. Curated by E. Ray Dorsey, MD, MBA.

Stay ahead of the curve at Neurology.org/innovations. 


\section{Neurology}

\section{Nerve ultrasound and 3D-MR neurography suggestive of intraneural perineurioma}

Alessandro Salvalaggio, Mario Cacciavillani, Daniele Coraci, et al. Neurology 2016;86;1169-1170

DOI 10.1212/WNL.0000000000002488

\section{This information is current as of March 21, 2016}

\section{Updated Information \& Services \\ Supplementary Material}

\section{References}

Subspecialty Collections

Permissions \& Licensing

Reprints including high resolution figures, can be found at: http://n.neurology.org/content/86/12/1169.full

Supplementary material can be found at: http://n.neurology.org/content/suppl/2016/03/19/WNL.0000000000002 488.DC1

This article cites 3 articles, 0 of which you can access for free at: http://n.neurology.org/content/86/12/1 169. full\#ref-list-1

This article, along with others on similar topics, appears in the following collection(s):

EMG

http://n.neurology.org/cgi/collection/emg

MRI

http://n.neurology.org/cgi/collection/mri

Nerve tumor

http://n.neurology.org/cgi/collection/nerve_tumor

Peripheral neuropathy

http://n.neurology.org/cgi/collection/peripheral_neuropathy Ultrasound

http://n.neurology.org/cgi/collection/ultrasound

Information about reproducing this article in parts (figures,tables) or in its entirety can be found online at:

http://www.neurology.org/about/about_the_journal\#permissions

Information about ordering reprints can be found online:

http://n.neurology.org/subscribers/advertise

Neurology ${ }^{\circledR}$ is the official journal of the American Academy of Neurology. Published continuously since 1951, it is now a weekly with 48 issues per year. Copyright @ 2016 American Academy of Neurology. All rights reserved. Print ISSN: 0028-3878. Online ISSN: 1526-632X.

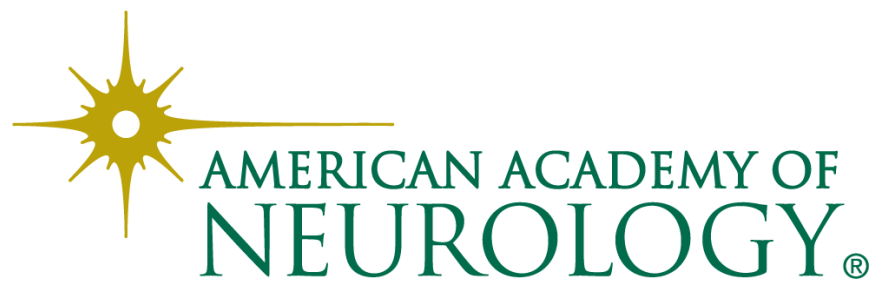

